\title{
A METÁFORA NA LINHA DE FRENTE: MAPEAMENTOS DE GUERRA NA CONCEPTUALIZAÇÃO DA PANDEMIA DE COVID-19
}

\section{METAPHOR ON THE FRONTLINE: MAPPINGS OF “WAR" IN THE CONCEPTUALIZATION OF THE COVID-19 PANDEMIC}

\author{
Solange Coelho Vereza ${ }^{1}$ \\ Universidade Federal Fluminense
}

\begin{abstract}
Resumo: Este artigo tem como objetivo propor e explorar, teórica e analiticamente, a metáfora conceptual COMBATE À PANDEMIA DE COVID-19 É GUERRA, com base em seus mapeamentos, instanciados em textos verbais e multimodais. A reflexão desenvolvida é empiricamente respaldada por dados coletados em resultados de busca da Plataforma Google e no Corpus do Português Online. A análise tem como foco os mapeamentos estabelecidos a partir de vários elementos-fonte estruturantes do domínio GUERRA, como "arma", "inimigo", "agonista/soldado" e "herói". A discussão será norteada pela hipótese de que mapeamentos seletivos perspectivam elementos-alvo do domínio COMBATE À PANDEMIA DE COVID-19, sendo sempre inseridos em uma dada situação discursiva, que, configurada por elementos contextuais, também participa do processo de perspectivação como um todo. A pesquisa se apoia nos seguintes conceitos teóricos, que se inserem na área da Linguística Cognitiva: metáfora conceptual, mapeamento, elementos-fonte e perspectivação. Esses conceitos também são mobilizados como unidades de análise dos textos examinados.
\end{abstract}

Palavras-Chave: Metáfora conceptual; Mapeamentos; Elementos-fonte; Perspectivação; pandemia COVID-19.

1 Endereço eletrônico: svereza@uol.com.br

52 № 69, NÚM. ESP.|2020, Salvador: pp. 52-89 
Abstract: This article aims to propose and explore, theoretical and analytically, the conceptual metaphor COMBAT AGAINST THE COVID-19 PANDEMIC IS WAR, on the basis of its mappings, instantiated in verbal and multimodal texts. The reflection developed is empirically supported by data collected in search results of the Google Platform and the Corpus do Português Online. The analysis focuses on the mappings established from various structuring source elements of the WAR domain, such as "weapon", "enemy", "agonist / soldier" and "hero". The discussion will be guided by the hypothesis that selective mappings profile target elements of the domain COMBAT AGAINST THE COVID-19 PANDEMIC, being always inserted in a given discursive situation, which, configured by contextual elements, also participates in the perspectivation process as a whole. The research is based on the following theoretical concepts, which fall within the area of Cognitive Linguistics: conceptual metaphor, mapping, source elements and perspective. These concepts are also mobilized as units of analysis of the texts examined.

Keywords: Conceptual metaphor; Mappings; Source-elements; Perspectivation; COVID-19 pandemics.

\section{INTRODUÇÃO}

Ao tratar das conceptualizações do evento que ficou conhecido como "O Onze de Setembro", ou "ataque às Torres Gêmeas", que abalou, no ano de 2001, os Estados Unidos da América e grande parte do mundo como um todo, Carvalho (2006) discorre sobre o que muitos americanos se referiam como uma "falta de palavras", resultante do espanto vivenciado por quase toda a população estadunidense diante da enormidade daquele acontecimento. $\mathrm{O}$ autor cita um artigo que havia sido publicado no jornal New York Times, que trata das expressões usadas, com frequência, por jornalistas, nos dias que se seguiram ao ataque, entre elas: "além da compreensão", "além de nossos piores temores", "além da imaginação" e "não há palavras que deem conta dessa barbárie", usadas para expressar a falta de sentido e a constatação de que "as palavras falharam naquela semana".

O artigo, segundo Carvalho (2006), relata ainda que, diante do que podemos entender como uma "escassez do significante" (SALOMÃO, 1999),

pessoas lançavam mão de metáforas e analogias que pudessem captar a tragédia do que haviam visto; entre elas: "um círculo do inferno de Dante"; "a erupção do Monte Santa Helena"; "inverno nuclear", "à beira da cratera de um vulcão"; "maior que Hindenburg"; "maior que o Titanic", e "Pearl Harbour" (CARVALHO, 2006, p.11). 
Frequentemente hiperbólicas, as metáforas, nesse caso, pareciam projetar, com alguma fidelidade, a intensidade do sentimento ou reação perante "o horror - the horror", para fazermos uma alusão ao famoso enunciado do filme Apocalypse Now, dirigido por Francis Ford Coppola. Evocando domínios-fonte relacionados à destruição e à morte causadas por acontecimentos históricos (Pearl Habour, Titanic, Hinderburg), desastres naturais (Monte Santa Helena) ou até por alegorias ou situações hipotéticas (inferno de Dante, à beira da cratera de um vulcão, inverno nuclear), as metáforas, aparentemente não convencionais, mesmo aludindo a conhecimentos enciclopédicos muito provavelmente compartilhados, não pareciam, necessariamente, hiperbolizar a total perplexidade e sentimentos de pavor experienciados por grande parte da população, naquele contexto.

A pandemia do Coronavírus SARS-CoV-2, conhecido metonimicamente, pelo nome da doença causada pelo vírus (COVID-19), abalou a saúde, a economia e o cotidiano das pessoas e suas relações profissionais e sociais, durante praticamente todo o ano de 2020. Ao escrever este artigo, já no fim desse ano, vemos a pandemia em plena "segunda-onda" no Brasil, com quase mil mortes e milhares de casos de infeção, diariamente. Aguarda-se, com muita expectativa, a chegada de uma vacina, mas, até lá, muitos de nós teremos que dar conta, com uma mistura de medo, ansiedade e esperança, da vida que segue atrás das portas e janelas de nossos "contêineres".

No entanto, ao contrário do cenário do "Onze de Setembro", em que as decorrentes conceptualizações metafóricas pareciam não dar conta do choque vivenciado imediatamente à dramática queda das duas torres, a pandemia do coronavírus, mesmo com sua dose também altíssima de "horror", parece ter se ancorado, cognitiva e discursivamente, em uma representação metafórica já bem estabelecida em nosso sistema conceptual e/ou inconsciente cognitivo: a metáfora da guerra.

Conceitos novos, instanciados por termos pouco frequentes na linguagem cotidiana, em sua maioria provenientes de áreas técnico-científicas, como os de 
"pandemia", "isolamento/distanciamento social", "higienização de alimentos", "infectologista", “epidemiologista", "álcool-gel", "quarentena", "lock down", "média-móvel", "achatamento da curva", "grupo de risco", entre outros, passaram a povoar os discursos circulantes sobre a pandemia, até mesmo entre os leigos no assunto. Esse conjunto de termos, entre outros aqui não mencionados, que, na perspectiva cognitivista, representaria alguns dos elementos do frame ${ }^{2}$ (FILLMORE, 2006; 2009) PANDEMIA, vem sendo divulgado por meio de programas e noticiários televisivos, mas, principalmente pela Internet. Nesse sentido, as redes sociais, segundo Zavaglia (2020), cumprem importante papel social, "divulgando terminologia da medicina, biologia e das ciências, que acabam entrando na nossa visão de mundo. Essas palavras acabam dando uma credibilidade para que as pessoas acreditem na doença" (ZAVAGLIA, apud STOCK, 2020, p.9).

Apesar da clara associação entre alguns desses conceitos e esquemas imagéticos (JOHNSON, 1987), como DISTÂNCIA-PROXIMIDADE e CONTENÇÃO ("distanciamento social" e lock down, por exemplo), muitos deles ("pandemia", "grupo de risco", "infectologista", "epidemiologista", por exemplo) podem ser abordados como instâncias de significado literal, em sua dimensão epistêmica, sem necessariamente evocar metáforas conceptuais - a não ser em uma perspectiva etimológica. No entanto, neste trabalho, partimos da hipótese de que a forma com que a pandemia é abordada - tanto na reação psicológica e comportamentos por ela motivados, quanto na ação - por parte de médicos, cientistas e da população como um todo -, evoca, bem mais nitidamente, uma metáfora conceptual: COMBATE À PANDEMIA/COVID-19 É GUERRA.

\footnotetext{
2 Segundo Fillmore (2009, p. 25.), o conceito de frame diz respeito a "qualquer sistema de conceitos relacionados de tal modo que, para entender qualquer um deles, é preciso entender toda a estrutura na qual se enquadram; quando um dos elementos dessa estrutura é introduzido em um texto, todos os outros elementos serão disponibilizados automaticamente". "Elementos do frame", portanto, poderiam ser abordados como sendo equivalentes a subcategorias que, em seu conjunto, estruturariam a categoria maior "frame".
} 
Este artigo, portanto, pretende se debruçar, conceitual e analiticamente, sobre essa metáfora, propondo um desenho dos possíveis mapeamentos que as constituem e que, ao mesmo tempo, delas derivam. A segunda hipótese a ser explorada é a de que a perspectivação característica dos mapeamentos (FAUCONNIER, 1997; TURNER, 1998), no nível cognitivo-discursivo, que faz com que se iluminem alguns elementos de um domínio e se apaguem outros (higlight e hide, segundo Lakoff e Johnson, (2002 [1980]) é, em grande parte, responsável pelo modo com que pensamos, falamos e agimos - para seguir, novamente, um dos postulados fundantes da Teoria da Metáfora Conceptual (TMC), propostos por Lakoff e Johnson (2002 [1980]).

O artigo está organizado em três partes, além desta introdução. Em primeiro lugar, trataremos dos eixos teórico-conceituais que apoiam a nossa reflexão: a metáfora conceptual (LAKOFF, 1993; LAKOFF e JOHNSON, (2002 [1980]); KÖVECSES, 2016; GIBBS, 2017), a noção de mapeamento (FAUCONNIER,1997; TURNER, 1998) e a questão da perspectivação no âmbito da metáfora (LANGACKER, 2013, SEGUNDO, 2007; SILVA, 2008). Todos os três eixos (metáfora, mapeamento, perspectivação) se circunscrevem no campo teórico da Linguística Cognitiva (LC), habitando algumas das ilhas desse arquipélago, para usar a metáfora introduzida por Geeraerts (2006), frequentemente empregada na literatura da área.

A seguir, o nosso foco recairá, mais detalhadamente, na metáfora aqui apresentada, que tem como domínio-fonte GUERRA. A reflexão a ser conduzida será ilustrada com exemplos de instanciações dessa metáfora identificados em textos encontrados em corpora autênticos: artigos de jornal, manchetes e memes de internet, que têm como tema a Pandemia de COVID-19. Amostras de páginas com resultados de buscas na ferramenta GOOGLE também farão parte dessa análise. A discussão proposta em torno da metáfora COMBATE À PANDEMIA/ COVID-19 É GUERRA terá como fio condutor a questão da perspectivação, a partir dos mapeamentos identificados. Fechamos o artigo com as considerações 
finais, em que se discutem os resultados e apontam-se possíveis implicações e encaminhamentos futuros da pesquisa.

\section{METÁFORA CONCEPTUAL, MAPEAMENTOS E PERSPECTIVAÇÃO}

A metáfora conceptual COMBATE À PANDEMIA/COVID-19 É GUERRA pode ser abordada como uma sub-metáfora decorrente de outra mais abrangente: COMBATE À DOENÇA É GUERRA, já bastante estudada, principalmente no contexto do tratamento do câncer (SEMINO et al., 2018). Metáforas de doenças têm recebido atenção na literatura, principalmente após a publicação do clássico livro de Sontag (1978), sobre as metáforas do câncer e, posteriormente, sobre a AIDS (2009). A doença como domínio-fonte, por sua vez, é evocada para contextualizarem-se situações avaliadas como negativas, como nos exemplos ${ }^{3}$ : “o racismo é um câncer social; "a corrupção é um câncer". Mesmo explorando a metáfora de forma original e inspiradora, no cenário das duas doenças, Sontag não apoiou sua análise na Teoria da Metáfora Conceptual (TMC), o que certamente não diminui a sua inegável contribuição. No entanto, tratamos a metáfora, em nossa pesquisa, a partir da perspectiva cognitivista; ou seja, o conceito de metáfora que dá base ao nosso estudo é o de "metáfora conceptual" convencionalmente grafada em caixa-alta.

A metáfora conceptual se difere, fundamentalmente, da metáfora tradicionalmente conceituada pela sua dimensão cognitiva: ou seja, o lócus da metáfora não estaria na superfície da linguagem; não sendo apenas um recurso retórico ou de embelezamento poético. A metáfora não só habitaria, mas também estruturaria, junto a outras representações cognitivas, como Modelos Cognitivos Idealizados (MCI), frames e esquemas imagéticos (LAKOFF, 1987), nosso sistema conceptual, a partir do qual pensamos, falamos e agimos e que é, segundo Lakoff

\footnotetext{
${ }^{3}$ Exemplos retirados da primeira página com os resultados da busca, efetuada na Plataforma GOOGLE, com a expressão "é um câncer".
} 
e Johnson (2002 [1980] p. 3), “fundamentalmente metafórico pela sua própria natureza".

A metáfora conceptual, que abre o livro que introduziu os pilares da TMC, o clássico Metaphors we live by, é DISCUSSÃO É GUERRA, cujas evidências encontradas na língua inglesa, principalmente a estrutura argumental dos verbos e itens lexicais já cristalizados, mostram como a própria estrutura e o léxico da língua retrata e dissemina essas metáforas ("Ganha-se" ou "perde-se" uma discussão, cria-se "estratégias" argumentativas, "conquistam-se" o interlocutor com um argumento, "defende-se uma posição" etc.).

No que diz respeito à linguagem, essa passa a ser, dentro da TMC, a fonte de evidências (as expressões linguísticas metafóricas) que marcam ou instanciam metáforas conceptuais subjacentes, que as "licenciam".

No caso da metáfora, essa relação seria estabelecida, cognitivamente, entre dois domínios: o domínio-fonte e o domínio-alvo (LAKOFF, 1993), caracterizando uma projeção da fonte para o alvo; daí o "transporte", e não uma relação qualquer. A projeção não é estabelecida, no entanto, entre os domínios como um todo, mas apenas entre elementos específicos do domínio A (fonte) e elementos relacionáveis (ou relacionados pela própria projeção) do domínio B (alvo). Ou seja, no caso da metáfora, haveria um mapeamento interdomínio, em que elementos de um domínio são mapeados sobre elementos do domínio-alvo. Nesse sentido, Fauconnier (1997 p. 9, tradução nossa) sugere que esses "mapeamentos projetam parte da estrutura de um domínio para outro" estruturando tanto metáforas conceptuais (LAKOFF, 1993), compartilhadas cognitivamente pelos membros de uma dada cultura, quanto metáforas situadas, produzidas deliberadamente em eventos comunicativos específicos (VEREZA, 2020).

${ }^{4}$ No original: Mappings will project part of the structure of one domain onto another. (Nossa tradução). 
Os mapeamentos que estruturam uma metáfora conceptual estabelecem suas projeções a partir de elementos específicos do domínio-fonte, que, neste artigo, denominaremos "elementos-fontes", em um processo já descrito por Lakoff e Johnson (2002 [1980]) como "realçar e encobrir" (highlight e hide), que resulta em mapeamentos seletivos ou perspectivados. Que elementos-fonte serão projetados para quais elementos-alvo em uma metáfora? O mapeamento seletivo, ou seja, a projeção de algum (alguns) elementos-fonte e não outros como, por exemplo, o brilho e a luz do Sol, e não seu tamanho e formato redondo, na metáfora Julieta é o Sol - pode ser entendido como um tipo de "perspectivação conceptual", que, de acordo com Silva (2008), seria "o modo e os modos alternativos de conceptualizar determinada situação. Esses modos alternativos envolvem operações de perspectivação conceptual e estas operações correspondem a capacidades cognitivas gerais". (SILVA, 2008, p.18).

Ainda segundo Silva, (2008), a metáfora não está incluída nas classificações de perspectivação conceptual propostas por Langacker (2013) e Talmy (1988), mas aparece na classificação proposta por Croft e Cruse (2004). A perspectivação que estamos propondo aqui diz respeito não especificamente à metáfora conceptual com um todo, mas à seleção de determinados elementosfonte e não outros. Os que são mapeados perspectivam o elemento-alvo de um modo específico, e apagam outros, como em um esquema de figura-fundo, aos moldes de Talmy (1978), que seria análogo ao processo de "highlighting e hiding" proposto por Lakoff e Johnson (1980, [2002]).

A discussão a seguir, empiricamente respaldada por dados coletados em resultados de busca da Plataforma GOOGLE e no Corpus do Português Online, irá se debruçar sobre os mapeamentos estabelecidos a partir de elementos-fonte estruturantes do domínio GUERRA considerados, neste estudo, como sendo mais centrais. A reflexão será norteada pela hipótese de que mapeamentos seletivos perspectivam elementos-alvo do domínio COMBATE À COVID-19, de um modo específico e não de outro, sendo sempre inseridos em uma dada 
situação discursiva, que, configurada por elementos contextuais, também participa da perspectivação como um todo.

\section{A GUERRA CONTRA O VÍRUS: MAPEAMENTOS EM PERSPECTIVAS BÉLICAS}

Pensar e falar sobre o enfrentamento de uma doença como combate ou guerra não é um fenômeno recente, muito menos exclusivo do cenário da pandemia da COVID-19. Afinal, como sugere Ling (2010),

doenças ou vírus não fazem parte do corpo humano. Se eles tentarem entrar no corpo humano, eles são conceptualizados como "invasores". Quando o vírus penetra no corpo, o paciente tem que resistir à doença para sobreviver. Nesse sentido, vírus ou doenças são concebidos como inimigos contra quem as pessoas deveriam lutar. (LING, 2010, p.19) ${ }^{5}$

Essa "luta", quando toma forma mais estruturada, mobilizando um aparato de ação bem mais amplo, envolvendo médicos, tratamentos, medicamentos etc., estende-se para um campo complexo e intrincado, que mantém de "luta" sua característica prototípica: o antagonismo e o objetivo de, de algum modo, vencer ou neutralizar o inimigo/opositor/antagonista ${ }^{6}$. Em outras palavras, a luta torna-se GUERRA, um frame que, enquanto domínio-fonte para vários domínios-alvo, como DISCUSSÃO (LAKOFF; JOHNSON, 2002 [1980]), SUCESSO (BRONZATO, 2012), POLÍTICA (FILIPCZUK, 2016) e ANTAGONISMO VERBAL (VEREZA, 2020), entre outros, é muito produtivo e

\footnotetext{
${ }^{5}$ No original: Diseases or virus are not a part of a human body. If they attempt to enter into the human body, they are conceptualized as "invaders". When the virus pervades in the body, the patient has to resist the disease in order to survive. In this sense, virus and diseases are conceived as enemies who people should fight against. (Nossa tradução)

${ }^{6}$ Neste artigo, usamos o binômio "agonista/antagonista" para caracterizar os elementos-fonte que representam, no domínio da GUERRA, aqueles (o agonista: país, sociedade, indivíduo) que sofrem o ataque do inimigo (o antagonista: o Coronavírus, a COVID-19). O agonista, em combate, em situação de contra-ataque, passa a ser perspectivado como antagonista: a vítima que vira combatente. Os termos em questão são elementos-chave no esquema da "dinâmica de forças", proposto por Talmy (1988), no contexto da Semântica Cognitiva, e são aqui convocados fora da perspectiva gramatical original.
} 
abrangente em várias línguas e culturas. A metáfora de guerra é tão infiltrada na língua inglesa, por exemplo, que, segundo uma pesquisa conduzida por Karlberg e Buell (2005), 17\% de todos os artigos da Revista TIME, publicados entre 1981 e 2000, continham, pelo menos, uma metáfora (linguística) de guerra.

Sendo assim, não é de se estranhar que o frame de GUERRA ${ }^{7}$ seja evocado para se pensar, falar e agir sobre a doença - provavelmente um dos mais temidos "inimigos" dos seres humano, talvez pelos seus efeitos no corpo e possível associação com a morte, e seu "combate". Segundo Wicke e Bolognesi (2020), o frame de GUERRA,

usado em discursos sobre doenças, é certamente convencional e frequentemente usado, muitas vezes de forma inconsciente [...] Tal quadro é prático e evocado com frequência porque se baseia no conhecimento básico que todos já possuem, mesmo que, para a maioria das pessoas, isso não seja um tipo de conhecimento vindo de experiências diretas ou de primeira-mão. Além disso, esse enquadramento conceptual expressa, de forma exemplar, a urgência associada a uma situação muito negativa, e a necessidade de ações a serem tomadas diante dessa situação, a fim de alcançar um resultado final rapidamente. (WICKE; BOLOGNESI, 2020, p. 5) ${ }^{8}$

A metáfora da guerra, no cenário da cura, tratamento ou enfrentamento de doenças tem sido bastante pesquisada dentro do campo da Linguística Cognitiva. Semino et al. (2018), por exemplo, exploram, em seu estudo, as conceptualizações de uma doença que é responsável por milhões de mortes, anualmente ${ }^{9}$, em todo o mundo: o câncer. A pesquisa revelou que as duas metáforas conceptuais mais mobilizadas nos discursos de pacientes de câncer

${ }^{7}$ Neste trabalho, metáforas conceptuais e frames são grafados em caixa-alta, como já convencionado na literatura. Elementos do frame (fonte e alvo) são grafados em caixa-baixa, entre aspas.

${ }^{8}$ No original: The figurative frame of WAR, used in discourses around diseases, is certainly a conventional one, frequently used, often unconsciously. [...] Such a frame is handy and frequently used because it draws on basic knowledge that everyone has, even though for most people this is not knowledge coming from first-hand experience. Moreover, this frame expressed in an exemplary way the urgency associated with a very negative situation, and the necessity for actions to be taken, in order to achieve a final outcome quickly. (Nossa tradução) ${ }^{9}$ De acordo com o website Our World in Data (www.ourworldindata.org/cancer), por volta de 10 milhões de pessoas morrem, anualmente, de câncer, sendo que, em 2017 o número de mortes foi de 9,6 milhões. 
eram as que tinham como domínios-fonte BATALHA (battle) e VIAGEM (journey). No primeiro caso, que interessa mais diretamente ao nosso propósito, BATALHA parece enquadrar mais coerentemente um cenário em que a doença afeta, em um dado momento, um único indivíduo, que recebe tratamento a ele/ela direcionado. Os indivíduos travam batalhas contra o câncer, contra doenças autoimunes, cardiopatias, entre outras enfermidades, mas contra uma epidemia, que atinge, simultaneamente, a sociedade como um todo, declara-se guerra. Quando a epidemia se espalha e atinge o mundo como um todo, tornando-se uma pandemia a guerra adquire dimensão global e todas as nações, cada qual com suas estratégias armas e recursos, passam a lutar contra um único inimigo.

Se uma epidemia como a da Dengue, cujas metáforas bélicas foram tratadas por Carvalho (2009), mobiliza vários elementos projetados do domíniofonte GUERRA, uma pandemia, como a causada pelo vírus SARS-CoV-2, aciona, de forma cognitivamente coerente, uma gama ainda maior de mapeamentos originários desse domínio. Afinal, segundo o Observatório Covid-19, publicado na página da Fundação Osvaldo Cruz (Fiocruz) ${ }^{10}$ :

A pandemia de Covid-19, causada pelo vírus SARS-CoV-2, vem produzindo repercussões não apenas de ordem biomédica e epidemiológica em escala global, mas também repercussões e impactos sociais, econômicos, políticos, culturais e históricos sem precedentes na história recente das epidemias.

Portanto, pela escala da pandemia e pelos múltiplos efeitos devastadores que ela produz, conceptualizar o seu enfrentamento, junto com as ações e sujeitos envolvidos nesse combate, a partir de um cenário de GUERRA, torna-se um processo cognitivo consistente, abrangente, marcado e, ao mesmo tempo, reificado pela linguagem.

A conceptualização da pandemia como GUERRA instancia-se na linguagem, o que pode ser evidenciado pela quantidade e pelo uso frequente de

${ }^{10}$ Disponível em: https://portal.fiocruz.br/impactos-sociais-economicos-culturais-e-politicosda-pandemia. Acesso em: $01 \mathrm{dez} .2020$. 
termos relacionados ao campo semântico de "guerra". Esse fenômeno é investigado por muitos estudiosos da linguagem, que oferecem explicações por vezes distintas. Penido (2020), por exemplo, ao comentar sobre o uso do termo "guerra" para se referir à pandemia, por exemplo, afirma, a partir de uma perspectiva histórica, que:

Desde que a pandemia do Covid-19 chegou às terras brasileiras, a palavra "guerra passou a fazer parte corrente do vocabulário do país. Não é um fenômeno novo, já que em virtude do passado militarizado latinoamericano, por aqui travam-se guerras contra a pobreza, contra as drogas, contra o analfabetismo, contra a dengue, e não seria diferente com o coronavírus. Também não é nova a relação entre a saúde e a guerra, uma vez que a profissão de enfermagem, por exemplo, nasce nesses ambientes. Por fim, um elemento que favorece a percepção da pandemia como guerra (assim como da segurança pública) é o alto número de mortos. (PENIDO, 2020, p.1)

A constatação empírica mais evidente da ubiquidade da metáfora da GUERRA em nossa língua e cultura é a própria cristalização de expressões contendo a palavra "combate" como núcleo do sintagma nominal que, por sua vez, tem como complemento nominal "pandemia" (combate à pandemia), “COVID-19" (combate à COVID-19) e Coranavírus (combate ao Coronavírus). De fato, o termo "combate" é tão largamente convencionalizado nessas expressões e em várias outras que se referem ao enfrentamento a doenças de um modo geral, que é praticamente impossível pensar em um termo literal equivalente que possa substituí-lo.

A fim de ilustrar esse uso de "combate" para se referir ao enfrentamento a doenças, uma pesquisa na plataforma Corpus do Português, com o item lexical "combate", indicou um número significativo de usos relacionados ao frame DOENÇA. 
Figura 1 - usos metafóricos de "combate"11

A $\mid$ B $|C|$ consumidos indiscriminadamente podem transformar pequenos buraquinhos em verdadeiras crateras. Para te ajudar no combate a principal vilã

A $\quad$ B $\quad$ C combater e cicatrizar infecçōes mais rápido; proporciona maior resistência aos nossos tecidos; combate os radicais livres; atua como anti-inflamat

A $\quad$ B $\quad$ C lesão por esforço repetitivo. Mas, não para por aí, este nutriente também combate sequelas de infarto, combate a depressão, ajuda no tratamentc

A B C Mas, não para por aí, este nutriente também combate sequelas de infarto, combate a depressão, ajuda no tratamento do câncer, previne doenças

A B C brócolis e espinafres, e maças. Óleos vegetais também apresentam bons resultados no combate ao Alzheimer. Você pode utilizar sementes de câr

A B C . De acordo com a delegada Sheila Freitas, da Divisão de Investigação e Combate ao Crime Organizado (Deicor), a prisão foi fruto dum trabalho

A B C soja), selênio (castanhas) e silício (aveia) atuam no combate à flacidez cutânea "», indica Vanessa Metz, membro da Sociedade Brasileira

A B C lifting. Acupuntura Essa técnica milenar já vem sido usada há muito tempo para o combate a rugas. Segundo a dermatologista Vanessa Metz, a acı

A $\quad$ B $\quad$ C açúcar mascavo e os outros tipos mais escuros contêm antioxidantes, que ajudam no combate a algumas doenças e também na prevenção do enı

A B C , melhora o metabolismo do organismo (evitando o processo de glicação), combate o estresse e melhora a qualidade do sono. Além disso, combat

A B C , combate o estresse e melhora a qualidade do sono. Além disso, combate a flacidez, a celulite e a gordura localizada. 10. Dispensar o hidratante.

A B C Daniela Taniguchi. Também por conta de isso, a soja pode ajudar no combate aos sintomas da TPM e prevenir a osteoporose. FRUTAS COM VITAM

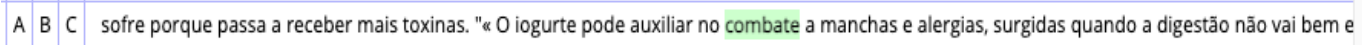

A B $C$ C 586182 Novo composto, chamado anthracimycin, parece ser efetivo no combate ao Staphylococcus aureus -- bactéria de fácil contágio por contatı

A B C , ressalta Fenical. 0 anthracimycin, que têm demonstrado sua eficácia no combate ao antrax e ao Staphylococcus aureus, indica o potencial dos oc

A B C C foi criado pelos hititas no ano mil a.C., quando os soldados em combate recebiam como alimento rações que consistiam em carne servida entre dı

A $\quad$ B C 586214 Gelo fecha os poros e uma colher gelada combate as olheiras Nutracêuticos, hidratantes, tensores, ácidos, vitaminas: os cosméticos estão

A B C as olheiras, proporcionado pela colher gelada, irá causar vasoconstrição, o que combate o acúmulo de sangue na região. No entanto, muito cuidac

A B C C estado, visando atender às comunidades com mais força e melhores resultados no combate à criminalidade... Leia Mais Foi reinaugurado na noite

A B C Polícia e a comunidade e principalmente para mostrar o funcionamento da Unidade no combate à criminalidade e a violência. "« A visita dos polici

Das vinte primeiras linhas de concordância que aparecem na pesquisa, dezessete delas indicam usos metafóricos de "combate" e três apontam usos literais (soldados em combate; combate à criminalidade, sendo que esta última ocorrência seria uma versão na interface metáfora/literal). No primeiro grupo, dez estão relacionadas ao campo da doença/saúde. Nelas, o combate tem como alvo radicais livres, sequela do infarto, depressão, Alzheimer, algumas doenças, estresse, sintomas da TPM, estafilococos, antraz, acúmulo de sangue. É interessante notar que, como já atestado na pesquisa de Faraco (2012), rugas, flacidez, manchas, celulite e olheiras, pelo menos na cultura ocidental, são exemplos da conceptualização de fatores estéticos como doença, um "inimigo a ser combatido".

O uso, portanto, de "combate", para se referir ao tratamento e à abordagem médica diante de doenças, mostra-se inequivocamente convencionalizado na língua portuguesa. É importante observar que a expressão "combate à COVID-19 ou ao Coronavírus" não aparece na pesquisa com o item "combate" no Corpus do Português. Isso pode ser explicado pelo fato de que esse

${ }^{11}$ Fonte: Corpus do Português Online. Disponível em: www.corpusdoportugues.org . Acesso em: 12 dez. 2020. 
corpus incluiu textos coletados até 2019, quando a pandemia de COVID-19 ainda não era uma realidade. Hoje, ao se fazer uma busca na Plataforma GOOGLE, com a expressão entre aspas, “combate à COVID-19", 10.200 .000 resultados são apresentados; e com a expressão "combate ao Corona vírus/ Coranavírus" o número é de 5.300.000. Lançar mão do termo "combate" para se referir ao enfrentamento de uma adversidade é uma escolha até mesmo previsível, uma vez que, como já mencionado neste artigo, o termo, de tão convencional, apresenta baixa "metaforicidade" (DIENSTBACH, 2017), ou seja, não é reconhecido, na maior parte de suas ocorrências, como uma metáfora.

É importante observar que, o frame de GUERRA seria, como já argumentado anteriormente, um domínio-fonte bem mais complexo e elaborado do que COMBATE, LUTA e BATALHA, por envolver uma gama bem maior de elementos-fonte estruturantes que são projetados em elementos específicos do domínio-alvo. No dicionário online da plataforma GOOGLE ${ }^{12}$, as seguintes definições para "luta", "batalha" e "guerra" são oferecidas:

Combate (ou luta): é um conflito violento cuja intenção é estabelecer dominância sobre o oponente.

Luta: MILITAR (TERMO): luta entre grupos pouco numerosos de forças militares, de extensão menor que a batalha; ESPORTE (TERMO), em que dois adversários desarmados se enfrentam em corpo a corpo.

Batalha: MILITAR (TERMO): combate entre forças oponentes, em terra, no ar e/ou no mar.

Guerra: MILITAR (TERMO): combate armado entre nações; conflito armado entre povos ou etnias diferentes, buscando impor algo pela força ou para proteger seus próprios interesses.

Com base nessas definições, "combate" parece ser o termo mais geral e semanticamente mais próximo à "luta" (há lutas marciais que adotam o temo “combate" para se referir a seus embates corpo-a-corpo) e "batalha". Esse último

${ }^{12}$ O Dicionário de Português do Google é proporcionado pela Oxford Languages. Disponível em: https://languages.oup.com/google-dictionary-pt/. Acesso em: 22 nov. 2020. 
termo tem seu uso literal ${ }^{13}$ mais frequentemente voltado para um conflito militar armado.

Já o sentido sugerido pelo dicionário para "guerra", ou seja, "combate armado entre nações", é corroborado por pesquisa feita no Corpus do Português, que apresenta os seguintes colocados, em ordem de frequência: mundial, civil, segunda, comercial, fria, fim, síria, crimes, trono e infinita. Uma análise das linhas de concordância de cada um desses colocados indica usos literais de "guerra" em quase todas as ocorrências, com exceção de comercial, trono e infinita (esses dois últimos com referência aos títulos de um seriado de televisão e de um filme, respectivamente). Além disso, as ocorrências têm como referência guerras específicas, como, por exemplo, a Segunda Guerra mundial, a guerra da Síria e a guerra fria entre os EUA e a antiga União Soviética, iniciada após a Segunda Guerra.

Como "conflito armado entre nações, povos e etnias", a complexidade do frame GUERRA, no sentido de envolver uma rede intricada tecida por um grande número de elementos, parece ser bastante evidente. Por essa razão, levanta-se aqui a hipótese da adequação cognitiva desse frame na conceptualização metafórica do enfrentamento da COVID-19, que também envolve muitos e complexos elementos.

Na plataforma GOOGLE, a busca com a expressão "guerra à COVID-19" produz 87.000 resultados; com “guerra à COVID”, 174.000; e com "guerra ao COVID", 8260, perfazendo um total de 269.260 entradas com os termos "guerra"

\footnotetext{
${ }^{13}$ Uma pesquisa no website do Corpus do Português indica que o item "batalha" é usado bem mais frequentemente em seu sentido metafórico do que no sentido literal (militar). Pesquisa com a expressão "batalha contra" revelou os seguintes complementos (os dez primeiros na lista apresentada pelo programa): batalha contra: imperialismo; esquecimento; desperdício de papel; imitações da China; desigualdade, pobreza; hiperinflação; câncer; alterações climáticas; dependência química; discurso de ódio - ou seja, todos com sentidos metafóricos.
} 
e "COVID". Já a busca feita com "guerra ao coronavírus" apresenta apenas 6740 entradas. Como já mencionado anteriormente, COVID-19 é um termo que tem sido usado para se referir tanto ao vírus (metonimicamente), quanto à doença por ele causada, por isso encontramos a preposição "a", complemento de "guerra", seguida tanto pelo artigo "a" ("guerra à COVID"), quanto pelo artigo "o" ("guerra ao COVID").

Sendo assim, a expressão "guerra à covid-19", a instanciação aparentemente mais explícita da metáfora conceptual COMBATE À COVID-19 É GUERRA, surge em notícias, memes, avisos etc., como mostra a Figura 2, que apresenta a primeira página dos resultados da busca feita com essa expressão na ferramenta de pesquisa GOOGLE.

Figura 2 - Usos de "guerra à COVID-19"14

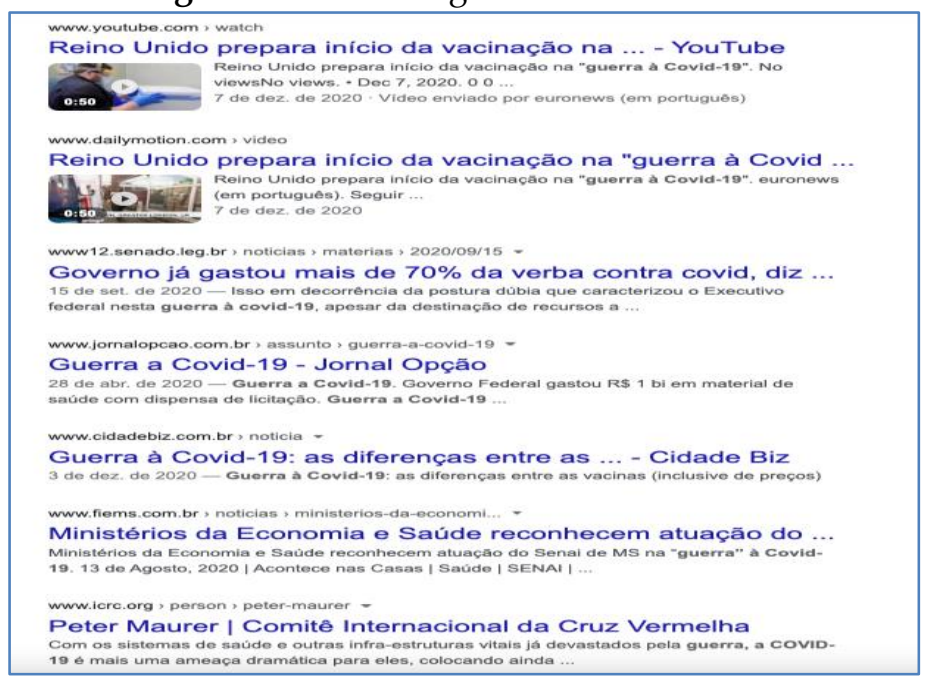

É interessante observar que algumas das ocorrências de "guerra à COVID19" estão grafadas entres aspas, ao contrário de "combate à COVID-19", que não aparece, em nenhum dos resultados, entre aspas. Isso sugere que há um certo reconhecimento da metaforicidade do uso de GUERRA como domínio-fonte, o que não acontece, como já visto anteriormente, com o uso metafórico, praticamente automático, de COMBATE.

${ }^{14}$ Fonte: Plataforma de Busca GOOGLE. 
A busca por "guerra ao Coronavírus" resultou em imagens, como as que seguem:

Figura 3 - Anúncios multimodais com "guerra ao Coronavírus"15
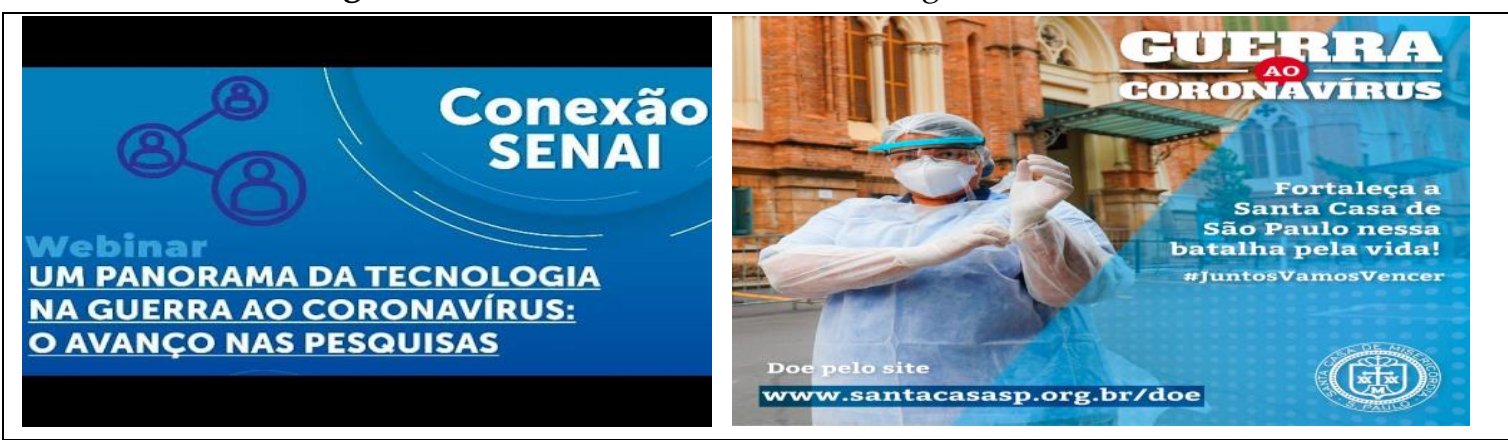

A primeira imagem da figura 3 trata de um anúncio para uma conferência, patrocinada pelo SENAC, sobre a "guerra ao Coronavírus". Já a segunda faz parte da campanha de doação promovida pela Santa Casa de Misericórdia de São Paulo. Ambas as imagens são promocionais e é possível se especular que o acionamento do frame GUERRA confere uma conotação de urgência às chamadas em questão.

Essa urgência projetada do frame GUERRA, como vimos nas palavras de Wicke e Bolognesi (2020) - "o enquadramento conceptual (" $x$ ” como GUERRA) expressa, de forma exemplar, a urgência associada a uma situação muito negativa" - e de Carvalho (2009), é também convocada, como mostra a figura 4, na manchete estampada nas capas de cinco jornais: O Globo, Folha de São Paulo, Valor, O Estado de São Paulo e Jornal Agora, publicados no mesmo dia 23/03/2020. A partir da campanha \#Imprensacontraovirus, os referidos jornais escolheram a manchete "Juntos vamos derrotar o vírus" como chamamento (quase uma “convocação") para união de todos na guerra contra o Coronavírus. O veículo expressão linguística metafórica, que instancia uma metáfora conceptual (CAMERON; TELMA, 2004) - "derrotar" evidencia o acionamento do frame

15 Fontes: 1: https:/www.senai-ce.org.br/fiec-noticias/134567/o-avanco-nas-pesquisas-etecnologias-no- combate-ao-novo-coronavirus-e-o-tema-do-proximo-webinar-do-senai-ceara. Acesso: 20 dez. 2020. 2https://www.facebook.com/santacasasp/photos/a.638193062920985/3822019817871611/ Acesso em: 20 dez. 2020. 
GUERRA, cujo elemento binário "vitória/derrota", além da gravidade do cenário e da urgência da ação em conjunto, é perspectivado no mapeamento.

Figura 4 - Manchete de jornais: derrotar o vírus ${ }^{16}$

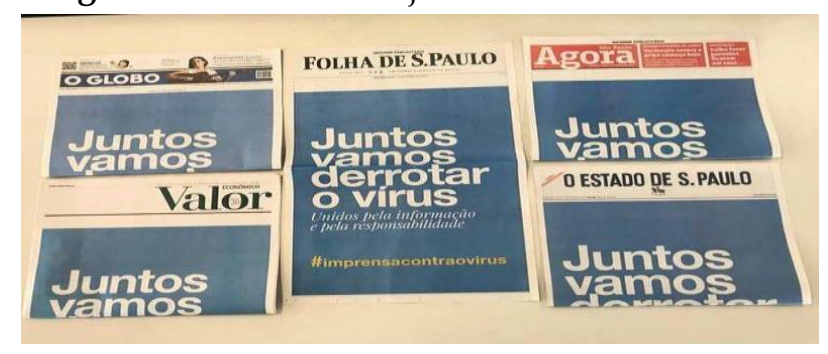

O domínio-fonte GUERRA, portanto, tem muitos de seus elementos projetados ou mapeados para o domínio-alvo COMBATE À COVID-19. O quadro 1 apresenta uma proposta do que consideramos ser seus principais mapeamentos, no contexto da pandemia do novo Coronavírus:

Quadro 1: mapeamentos de COMBATE À COVID-19 É GUERRA

\begin{tabular}{|c|c|}
\hline Domínio-fonte: GUERRA & $\rightarrow$ Domínio-alvo: COMBATE À COVID-19 \\
\hline Elementos-fonte & Elementos-alvo \\
\hline Inimigo/antagonista & Coronavírus/Covid-19/Pandemia \\
\hline Nação/ agonista & $\rightarrow$ Brasil, sociedade \\
\hline Estratégias de guerra & $\begin{array}{l}\text { Planejamento, políticas públicas, testagem, } \\
\text { medidas de restrição (fechamento de comércio/ } \\
\text { distanciamento social etc.) }\end{array}$ \\
\hline Soldados/combatentes/guerreiro/herói & Profissionais da saúde \\
\hline Linha de frente & $\begin{array}{l}\text { Linha de frente (tratar diretamente pacientes } \\
\text { em hospitais) }\end{array}$ \\
\hline Armas & $\begin{array}{l}\rightarrow \text { Vacina, medicamentos, uso de máscara, } \\
\text { higienização }\end{array}$ \\
\hline Baixas & $\rightarrow$ Óbitos \\
\hline Hospital de campanha & $\rightarrow$ Hospital de campanha \\
\hline Trincheira & $\rightarrow$ Isolamento social; lock down \\
\hline General & $\rightarrow$ Ministros/secretários de saúde \\
\hline Comandante das forças armadas & $\rightarrow \quad$ Presidente/Primeiro ministro \\
\hline Orçamento de guerra & $\rightarrow$ Orçamento de guerra \\
\hline União da sociedade contra o inimigo & $\rightarrow$ União da sociedade contra a COVID-19 \\
\hline
\end{tabular}

Fonte: Elaborado pela autora

https://www.em.com.br/app/noticia/nacional/2020/03/23/interna_nacional,1131663/imprensa -contra-virus-jornais-brasileiros-usam-a-mesma-capa-em-combat.shtml Acesso em: $20 \mathrm{dez}$. 2020. 
Os mapeamentos propostos no Quadro 1 indicam um grande número de projeções do domínio-fonte para o domínio-alvo, o que sugere uma proximidade cognitiva entre ambos tão significativa, que poderia até mesmo ser percebida como um caso de "quasi-equivalência conceptual", como se a guerra contra a Covid-19 fosse sentida pelas pessoas como sendo literal, uma guerra ipsis litteris. No entanto, o contraste entre literal e metafórico, mesmo que sutil, pode ser observado, com as lentes de um analista de metáfora, no seguinte depoimento, proferido por um médico neurologista intensivista, que trabalhou, durante quase todo o ano de 2020, na Unidade de Tratamento Intensivo do Hospital Albert Einstein, em São Paulo:

(1) “A minha geração não viveu uma guerra. Esta é a guerra de nossa geração. Com certeza foi o ano mais desafiador de nossas vidas"17.

O uso de "guerra" na primeira oração refere-se, por inferência, a uma guerra no sentido canônico. É notório que o Brasil, desde 1945, não esteve, pelo menos diretamente, envolvido, militarmente, em qualquer "guerra contra outras nações", para seguir a definição de dicionário apresentada anteriormente. Portanto, é razoável imaginar que, para o senso comum, a última geração que participou de um conflito militar armado, nesse sentido canônico, foi aquela dos chamados "Pracinhas", soldados e oficiais da Força Expedicionária Brasileira (FEB), que combateram na Segunda Guerra Mundial. Já na oração seguinte, com o uso do pronome demonstrativo dêitico "esta", infere-se que a guerra referida é a "guerra contra a COVID-19", a cuja linha de frente o médico pertence. O contexto da reportagem, em que o enunciado se insere, que trata do papel essencial dos profissionais de saúde durante a pandemia, conduz e respalda essa inferência. Pelo enorme desafio e grande sacrifício envolvidos para se combater o inimigo e, portanto, salvar vidas, colocando, como um soldado, a sua própria ${ }^{17}$ Depoimento do médico Felipe Viana, publicado em reportagem do Jornal O GLOBO, de 01
janeiro de 2021, p. 12. 
vida em risco, o médico vivencia, de fato, no plano cognitivo e diretamente sensório-motor, o cenário em que trabalha como um cenário de GUERRA.

\section{PERSPECTIVAÇÕES EM MAPEAMENTOS DO DOMÍNIO-FONTE GUERRA}

No quadro 1, os muitos mapeamentos estruturantes, e ao mesmo tempo decorrentes, da metáfora conceptual COMBATE À COVID-19 É GUERRA, em seu conjunto, evidenciam a força cognitiva da metáfora em questão. Não só pensamos na situação imposta pela pandemia (e seu combate) como uma situação de guerra, como também a vivenciamos e agimos como se ela, de fato, o fosse. Protegemo-nos do inimigo, usamos armas para combatê-lo, ficamos isolados em nossas trincheiras, enviamos os doentes para hospitais de campanha, dependemos de soldados - profissionais da saúde - na linha de frente, aguardamos a arma que provavelmente aniquilará o inimigo - a vacina - e que nos tirará do estado de guerra para comemorarmos a vitória final. Nesse cenário bélico, a vacina seria a nossa "arma nuclear", desenvolvida por um grupo de "cientistas aliados", a qual, com seu efeito destrutivo e devastador, garantirá a vitória final. Esse último mapeamento (vacina como arma nuclear) talvez não seja convencional - sendo possivelmente até mesmo inédito - como os outros propostos no quadro 1, mas, pela sua plausibilidade, é apenas um exemplo da produtividade consistente da metáfora conceptual que o licencia.

Analisando, mais detalhadamente, os mapeamentos sugeridos no quadro 1, observa-se que há aqueles que, de tão convencionalizados (e, portanto, com baixo grau de metaforicidade), já estão até mesmo lexicalizados. É o caso de "hospital de campanha", "linha de frente" e "orçamento de guerra18", cujos referentes não possuem um termo substituto "literal", apesar, é claro, de

18 "Orçamento de Guerra" foi o nome dado à Proposta de Emenda Constitucional (PEC) 10/2020. Essa proposta, criada no começo de 2020, faz alterações ao texto constitucional a fim de possibilitar maior flexibilidade aos gastos do governo federal. O objetivo é facilitar a tomada de medidas para combater a pandemia de Coronavírus e seus efeitos. Fonte: https://maisretorno.com/blog/termos/o/orcamento-de-guerra. Acesso em: 20 nov. 2020. 
poderem ser parafraseados. Ou seja, não há outro termo para se referir, por exemplo, à "hospital de campanha". Esses termos, portanto, passaram a frequentar o "vocabulário da pandemia" (STOCK, 2020), não sendo, provavelmente, sequer considerados metafóricos pela maior parte das pessoas.

Outros termos, porém, de caráter menos específico, como "inimigo", "armas" e "combatentes", não foram lexicalizados da mesma forma, apesar de terem elementos-alvo de certa forma previsíveis. São eles que serão analisados a seguir.

\subsection{Conceptualização do “inimigo" no COMBATE À COVID-19}

A projeção do elemento "inimigo", em um cenário de guerra, configura conceptualmente os seguintes domínios-alvo:

(2) Coronavírus, pandemia, vírus, Covid, Covid-19, Novo Coronavírus.

As instanciações do elemento "inimigo", do domínio-fonte GUERRA, em (2), foram encontradas entre os resultados da busca na Plataforma GOOGLE, com a entrada "guerra contra" + pandemia. A preposição "contra" requer, cognitivamente, um inimigo a ser combatido, e o termo "pandemia" foi incluído na busca com a finalidade de restringir os cenários da guerra em questão; daí os seis termos encontrados. O inimigo pode ser diretamente o vírus (Coronavírus, vírus, Novo Coronavírus), ou as suas consequências (Covid, Covid-19, pandemia), sendo que "vírus" e "doença" muitas vezes se confundem, pela metonímia realizada entre ambos.

A perspectivação que realça ou joga o foco sobre o elemento "inimigo" pode ser observada na figura 5. 
Figura 5 - vencer o "inimigo"19

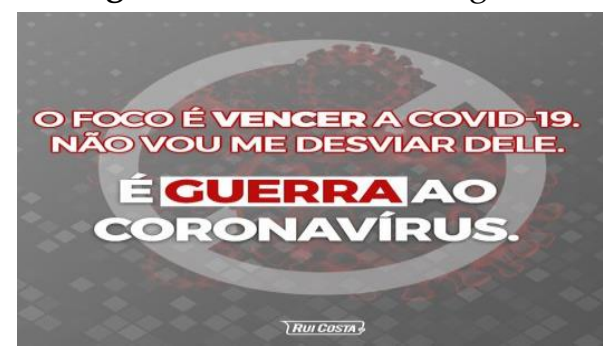

O que pode ser visto como um "grito de guerra" destaca, muito claramente, inclusive pelo uso do termo "foco", o inimigo a ser vencido: a COVID-19. A doença se confunde, mais uma vez, por metonímia, com o vírus que a causa: "é guerra ao Coronavírus". Trazendo o inimigo para o centro do palco cognitivo, a guerra torna-se mais nítida, exigindo coragem e bravura: "não vou me desviar dele".

Este "grito de guerra"20, com o "inimigo" perspectivado, também está presente na figura 4, uma vez que a manchete estampada nos 5 jornais (“Juntos vamos derrotar o vírus"), com o uso do verbo "derrotar", e o verbo "ir", na primeira pessoa do plural, precedido de "juntos", tem um efeito de gerar "motivação nos combatentes" - todos nós.

Apesar de invisível, podendo ser visto apenas através das lentes de potentes microscópios, o inimigo, como qualquer microrganismo, não pode ser considerado "abstrato". Sabemos que ele tem forma (daí o seu nome: corona, uma coroa) e pode ser fisicamente morto com lavagens de mão ou outras formas de higienização. Outros "inimigos", que ameaçam a segurança do ser humano, como o medo, o ódio, a perversidade, ou outros sentimentos, que, mesmo afetando as pessoas psicologicamente, e, por vezes, até fisicamente, também são

\footnotetext{
${ }^{19}$ Fonte: https://www.facebook.com/ruicostaoficial/posts/1942838312514970/. Acesso em: 20 dez. 2020.

${ }^{20}$ De acordo com o Dicionário Online de português (https://www.dicio.com.br/grito-de-guerra/), um grito de guerra é uma "palavra ou frase bradada em uníssono para excitar o entusiasmo das tropas em ataque: antes das batalhas, os soldados entoavam os seus gritos de guerra". Em uma busca na Plataforma GOOGLE, verificou-se que o termo também é usado no domínio dos esportes e da propaganda.
} 
alvos de guerra, mas a partir de um grau de metaforicidade (DIENSTBACH, 2017) bem mais elevado. Assim, a metáfora COMBATE À COVID-19 É GUERRA tem uma abrangência cognitivo-discursiva e uma força corpórea, proveniente da invisibilidade paradoxalmente material do inimigo, de tal dimensão, que seria razoável concebê-la como estando na fronteira com a literalidade, ou no extremo do continuum entre menor ou maior metaforicidade. O inimigo, um vírus, que, como todos de sua classe, "são os menores organismos existentes na natureza e os únicos que não possuem células; simplicidade, porém, não é um adjetivo para esses seres tão temidos" (BRUMATTI; FERRI, 2020).

A figura 6 apresenta imagens que evocam e perspectivam, verbal e visualmente, a conceptualização do vírus como inimigo: a primeira, uma imagem em um website jornalístico de divulgação científica; e a segunda, uma capa de livro - ambos, por meio de suas imagens, tornam visível e mais impactante o que é invisível, mas nem por isso menos letal.

Figura 6 - O inimigo invisível ${ }^{21}$
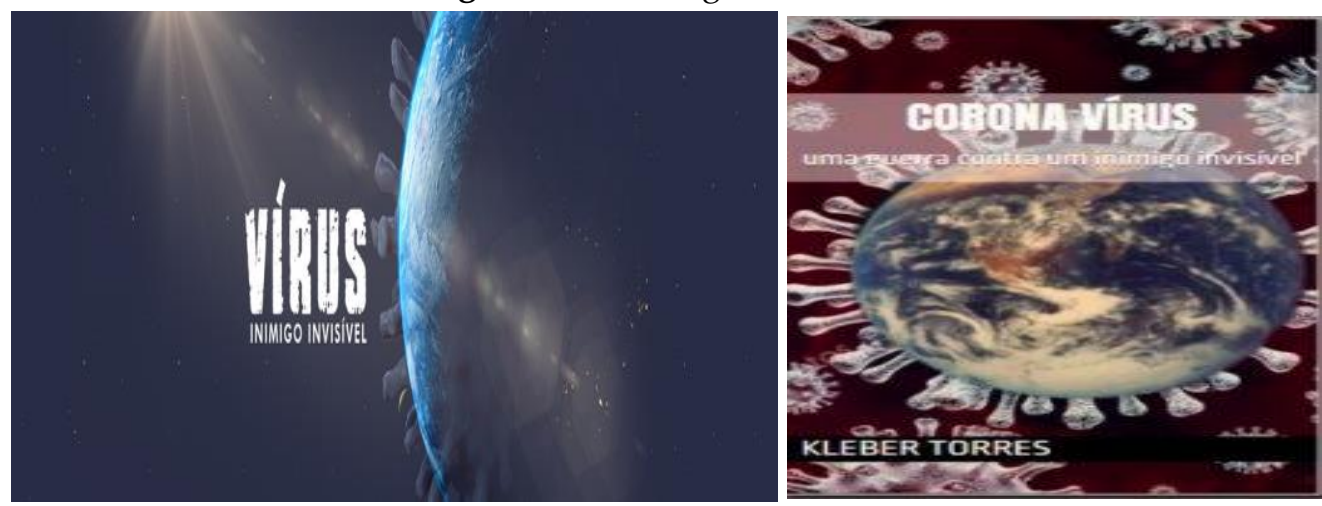

A imagem da figura 7, por sua vez, perspectiva o inimigo, não a partir de sua invisibilidade, mas de sua aparente invencibilidade, uma vez que seriam necessárias a força e a agilidade de um guerreiro de ficção para destruí-lo. Esse frame online, um cenário de videogame, no entrelace com frames off-line (VEREZA,

13 Disponíveis em: https:/g1.globo.com/sp/campinas-regiao/terra-dagente/noticia/2020/03/31/inimigo-invisivel-qual-e-a-cara-de-um-virus.ghtml; https://costadocacau.blog.br/livro-fala-da-guerra-contra-um-inimigo-invisivel-o-novocoronavirus/ Acesso em: 16 dez. 2020. 
2013), realça os atributos de movimento/velocidade e potencial destrutivo dos vírus, que, juntos, assemelham-se a projéteis explosivos ou bombas, armas típicas desses jogos eletrônicos (KIMBERLY; HANINGER, 2001). Na figura, inimigo e arma do inimigo se confundem: não há um inimigo por trás da arma- o inimigo é a arma.

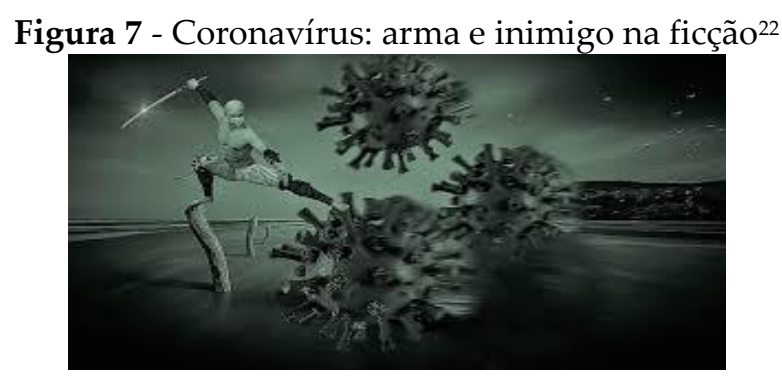

\subsection{O agonista: Brasil e a sociedade}

O elemento-fonte "agonista" parece ser, na maior parte das vezes, atualizado pelo próprio Brasil, que, como nação, torna-se, ao mesmo tempo, em uma espécie de "contra-ataque", vítima e algoz do "antagonista" (o inimigo), assumindo o papel de "guerreiro/soldado".

A figura 8 mostra a primeira página com os resultados da busca, na plataforma GOOGLE, com a expressão “Brasil contra o Coronavírus”. É relevante observar que as páginas em que "Brasil" é perspectivado como "guerreiro/soldado" contra o Coronavírus originam-se de fontes governamentais.

Figura 8 - Brasil/agonista contra o Coronavírus.

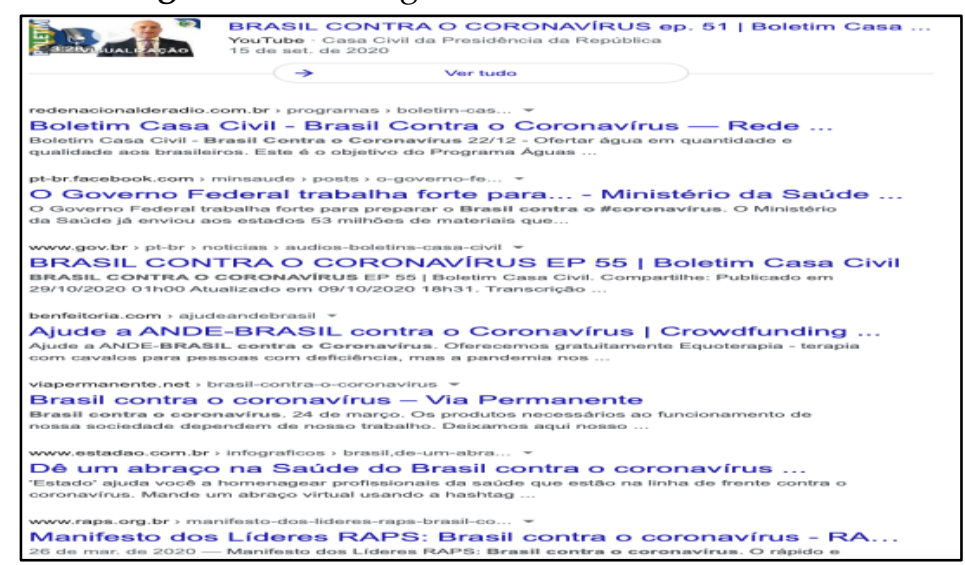

22 Fonte: https://jornal.ufg.br/n/131433-metafora-de-guerra-sobre-a-pandemia-afastaestimulo-a-cooperacao. Acesso em: 16 dez. 2020. 
Por outro lado, a figura 9 apresenta um anúncio da página da organização não-governamental (ONG) Sociedade Contra o Corona, que perspectiva a sociedade como ocupante do elemento-fonte "agonista", que vira antagonista a partir do momento que reage "contra o Corona". Essa ONG envolve dezenas de outras ONGs, como Educafro, OXfam, Ibase e Instituto sou da Paz, para citar algumas das mais conhecidas. Esse contraste parece demonstrar que a SOCIEDADE, nos dados, não está metonimicamente conceptualizada, pelos órgãos governamentais, como BRASIL, - esse sim perspectivado a partir de sua relação de metonímia com o próprio governo, cujo slogan - "Pátria Amada Brasil" também indica essa perspectivação metonímica (Pátria/Brasil/Governo).

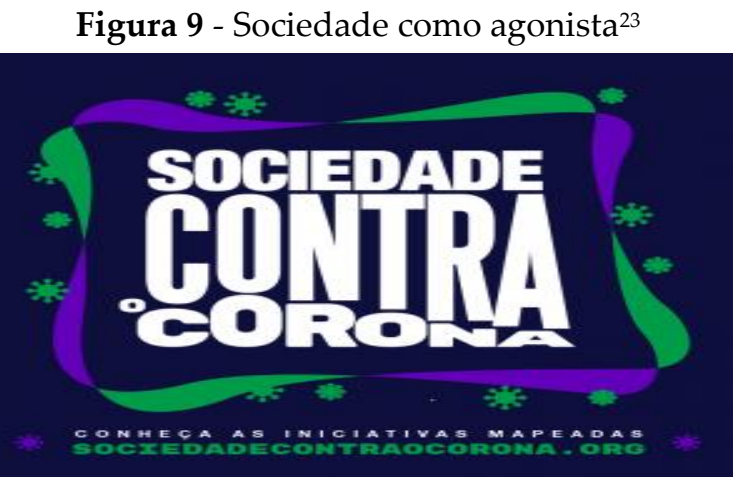

O binômio Agonista/Antagonista (TALMY,1988), ao ser perspectivado como o paciente (vítima do "inimigo" Coronavírus), que se torna agente de um "contra-ataque", em um cenário de GUERRA, ancora-se no elemento-fonte “soldado/combatente". Esse mapeamento será discutido a seguir.

Há um nítido e forte reconhecimento, por parte de pelo menos boa parte da sociedade, do papel imprescindível dos profissionais de saúde no combate ao Coronavírus/COVID-19. Uma pesquisa na plataforma GOOGLE com a expressão "reconhecimento aos profissionais da saúde" resultou em 21.200 páginas. A primeira página com os resultados apresentou os seguintes enunciados:

- MPPR presta reconhecimento aos profissionais de saúde pelos serviços prestados no combate à pandemia de Coronavírus;

${ }^{23}$ Fonte: https://osbrasilia.org/sociedade-contra-o-corona/ Acesso em: 17 dez. 2020. 
- Professor da UEPB é premiado no maior evento de reconhecimento aos profissionais de Saúde do Brasil;

- Para incentivar a população a enviar elogios em reconhecimento aos profissionais da saúde ...

- Ano de muito aprendizado e, acima de tudo, de reconhecimento aos profissionais de saúde;

- Circula nas redes sociais uma campanha de reconhecimento aos profissionais de saúde que trabalham para conter o avanço da epidemia;

- A Prefeitura de Londrina informou que abriu canais para receber mensagens de apoio e reconhecimento aos profissionais de saúde;

- Homenagem levou, além da música, o reconhecimento aos profissionais de saúde que atuam diariamente na assistência a quem necessita.

A partir do frame de GUERRA, os profissionais da saúde são perspectivados como "soldados" - um elemento-fonte central do domínio-fonte GUERRA - que defendem a sociedade e, ao mesmo tempo, atacam o "inimigo". Considerando o reconhecimento de toda a sociedade aos profissionais de saúde, esses não seriam soldados comuns, mas heróis na batalha, vivenciada por todos, contra a COVID-19. Esse heroísmo dos "soldados na guerra contra a COVID-19" pode ser observado nas seguintes imagens da figura 10, em que temos duas capas de revista, uma homenagem digital a profissionais de saúde e uma ilustração de um artigo sobre a "batalha no campo da saúde"

Figura 10 - Profissionais da saúde conceptualizados como heróis ${ }^{24}$

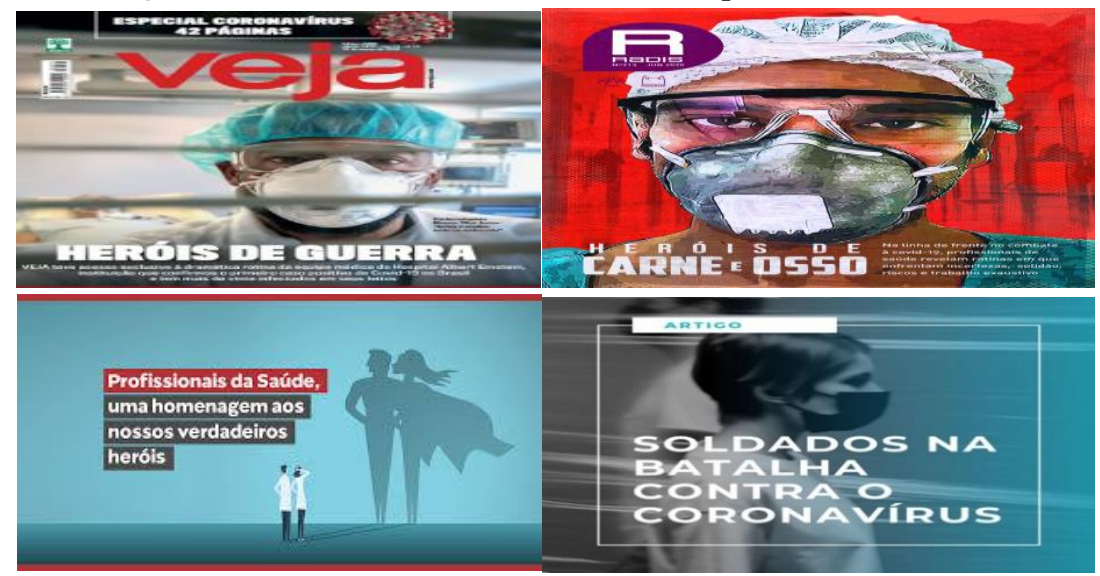

${ }^{24}$ Fontes:https://veja.abril.com.br/edicoes-veja/2679/;

https://radis.ensp.fiocruz.br/index.php/todas-as-edicoes/213;

https://grupoelfa.com.br/profissionais-da-saude-homenagem/;

https://ebdicorp.com.br/soldados-na-batalha-contra-o-coronavirus/. Acessos em: 16 dez. 2020. 
Um breve exame na plataforma GOOGLE com os termos "heróis e pandemia" revelou que não apenas os profissionais de saúde são conceptualizados como heróis, mas também "guerreiros" que atuam em outras profissões. Os dois textos a seguir, acompanhados de suas ilustrações, demonstram o alcance do elemento-fonte guerreiro/herói para além da área da saúde:

Figura 11- Super-heróis na pandemia ${ }^{25}$

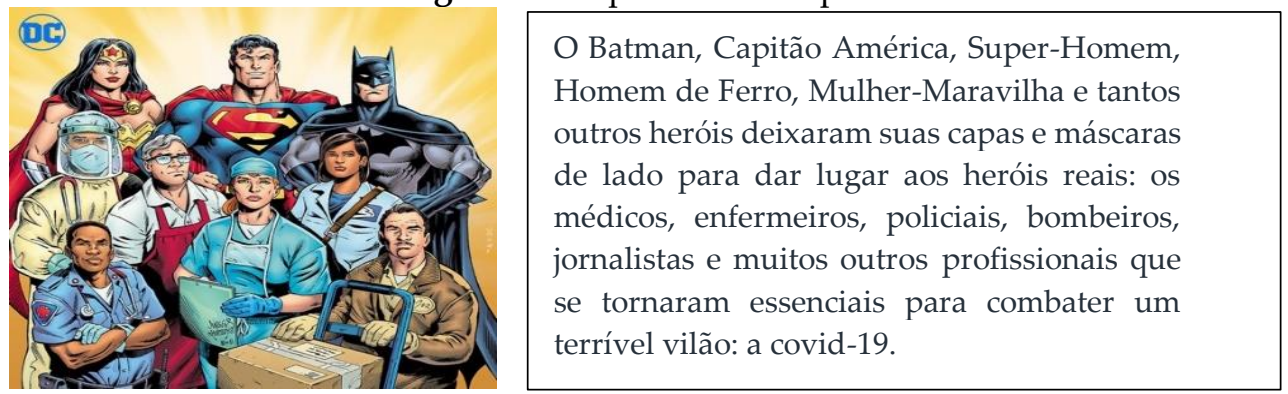

Figura 12 - Outros profissionais-heróis na pandemia 26

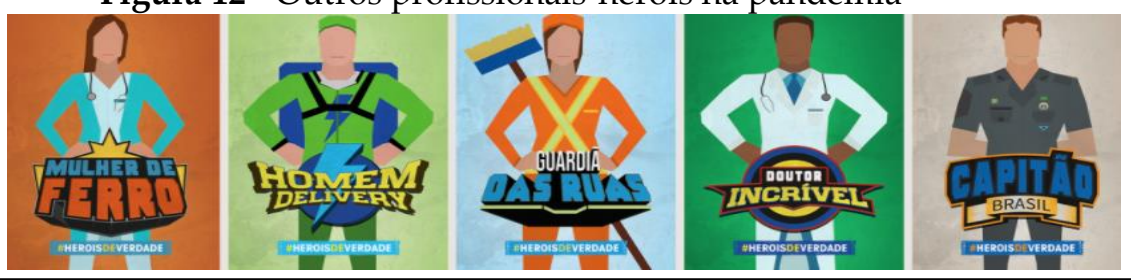

Neste momento complicado que estamos vivendo, existe uma coisa que ninguém discorda: médicos, enfermeiros, garis, entregadores, policiais. Todos são heróis nessa batalha. E todos esses profissionais, cada um na sua função, estão lutando contra o vilão para que a maioria das pessoas possa ficar protegida.

A perspectivação é de caráter fortemente avaliativo, uma vez que o modelo cultural de herói é o de um guerreiro excepcional, defensor e combatente, sempre munido de extrema valentia: “herói é aquele que se notabiliza por feitos guerreiros ou atos de grande coragem"27. E, a partir dessa projeção do elementofonte "guerreiro/herói" na conceptualização desses profissionais, "todos são heróis nessa batalha".

25 Fonte: https://www.meon.com.br/especial/herois-da-pandemia-profissionais-da-linha-defrente-falam-da-importancia-do-trabalho-durante-crise-da-covid-19 Acesso em: 16 dez. 2020.

26 Fonte: https://www.blogdoadonis.com.br/2020/04/15/os-herois-das-ruas/. Acesso em: 17 dez. 2020.

27 Dicionário Michaelis Online. Disponível em: https://michaelis.uol.com.br/modernoportugues/busca/portugues-brasileiro/her\%C3\%B3i/. Acesso em: 20 dez 2020. 
No entanto, mesmo com o reconhecimento da enorme ajuda de muitos profissionais no combate à pandemia do vírus, os combatentes que estão na "linha de frente" dessa batalha parecem receber admiração ainda maior por parte da sociedade, uma vez que estão em pleno "campo de guerra", frente-a-frente com o inimigo, arriscando (literalmente) as suas vidas e salvando (literalmente) outras. A primeira imagem da figura 3 mostra uma página de resultados da busca na Plataforma GOOGLE com a expressão "linha de frente", sendo que todos os resultados estão relacionados aos profissionais de saúde que atuam nesse contexto. A segunda imagem mostra uma equipe desses profissionais, médico(a)s, enfermeiro(a)s, técnico(a)s em enfermagem e fisioterapeutas ${ }^{28}$, formando a "linha de frente" - inclusive alinhados, na foto, nesta posição - do combate à COVID-19.

Figura 13 - Linha de frente no combate à COVID-929

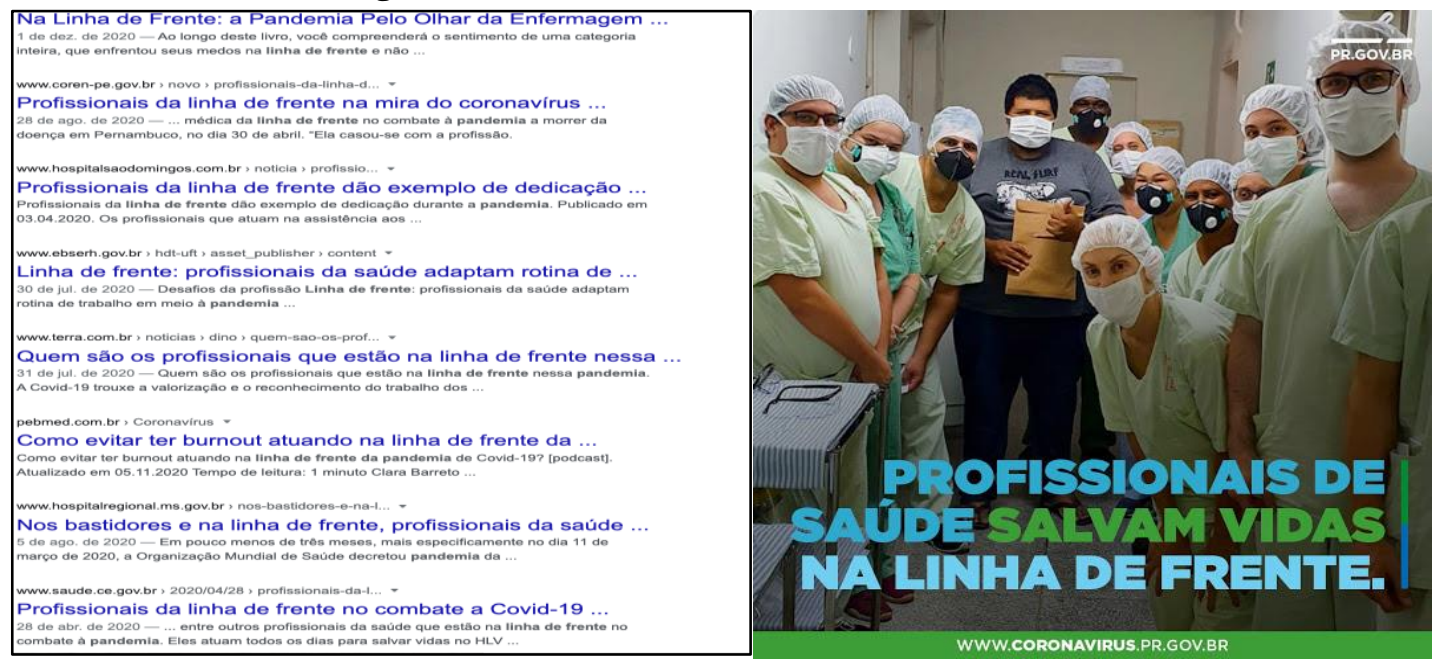

${ }^{28}$ É importante observar que esses profissionais de saúde formam o grupo mais diretamente associado à linha de frente no Combate à COVID-19, como mostra o resultado da busca no GOOGLE, na figura 13. No entanto, segundo reportagem publicada na página da CNN: "A linha de frente do combate à pandemia nos hospitais vai muito além dos profissionais da saúde. Incansáveis, os funcionários responsáveis pela limpeza, segurança, portaria, recepção e muitas outras funções essenciais também não tiveram descanso neste ano difícil. Disponível em: https://www.cnnbrasil.com.br/saude/2020/12/21/os-outros-profissionais-na-linha-defrente-do-combate-a-covid-19. Acesso em: 21 nov. 2020.

29 Fontes: Página de resultados http://www.coronavirus.pr.gov.br/Campanha/Pagina/Profissionais-de-saude-salvam-vidasna-linha-de-frente. Acesso em: 22 dez. 2020 
A “pressão" exercida sobre médico(a)s e enfermeiro(a)s, neste cenário de GUERRA, é sentida e percebida como sendo corporeamente mais próxima a uma situação real de batalha, como mostra o depoimento de dois desses profissionais:

(3) Um profissional de saúde atuando com a covid-19 hoje no Brasil pode estar dividido em dois grupos. De um lado, quem vive onde o sistema já colapsou, com a demanda ultrapassando a capacidade de atendimento - e aqui o cenário é de guerra, com as cenas a que temos assistido no Amazonas, Ceará e algumas regiões do Rio de Janeiro. Do outro, quem trabalha ouvindo o temporizador imaginário de uma bomba que ninguém sabe de fato quando - nem se - irá explodir. (Grifos nossos) ${ }^{30}$

(4) Por mais que a nossa classe já esteja lidando com pressão desde a faculdade, agora é como uma situação de guerra sem armas. (Grifos nossos) ${ }^{31}$

O qualificador ("sem armas"), complemento nominal de "guerra", no último depoimento, ressalta um aspecto importante da perspectivação: a guerra vivenciada é uma guerra sem armas. A explicitação do não mapeamento (ou não perspectivação; apagamento) do elemento-fonte "armas" parece indicar que, na conceptualização do combate à COVID-19 como GUERRA, projetam-se todos outros elementos, menos as armas. No entanto, como veremos a seguir, as armas são também mapeadas sobre outros elementos do domínio-alvo ao serem perspectivadas em uma dada situação discursiva.

\subsection{Armas contra o Coronavírus/Covid-19}

Em um cenário de guerra, cognitiva e discursivamente estabelecido, como vimos até agora, a perspectivação das "armas" (elemento-fonte fundante, juntamente com "inimigo, agonista/combatente") se impõe como um aspecto central na conceptualização do combate à COVID-19.

O grande número de entradas como resultado da pesquisa na Plataforma GOOGLE32, a partir das expressões "armas contra o Coronavírus" e "armas

\footnotetext{
${ }^{30}$ Fonte: https://diariodonordeste.verdesmares.com.br/metro/covid-19-profissionais-da-linhade-frente-travam-batalha-emocional-1.2236328. Acesso em: 22 dez. 2020.

${ }^{31}$ Disponível em: https://pfarma.com.br/coronavirus/5522-cotidiano-profissional-saude.html. Acesso em: 22 dez. 2020.

3235.900 resultados para "arma contra Coronavírus" e 41.400 para "arma contra COVID-19".
} 
contra a COVID-19", indica a centralidade das "armas" no combate à pandemia.

Das entradas apresentadas, selecionamos vinte, que consideramos os tipos principais e mais frequentes de "armas", nas cinco primeiras páginas de cada resultado (um tendo como alvo "coronavírus", outro "COVID-19").

Figura 14 - Entradas para "arma contra Coronavírus" e "arma contra COVID-19".

1. Lavar as mãos corretamente continua sendo uma forte arma contra o coronavírus.

2. Lâmpadas ultravioletas podem ser uma possível arma contra o coronavírus.

3. São Lourenço do Sul investe na sanitização como arma contra o coronavírus.

4. Os anticorpos monoclonais, uma arma contra o coronavírus. Millenium Explica.

5. Ação reforça a higiene como arma contra o coronavirus.

6. Prevenção é a única arma contra o coronavírus.

7. A maior arma contra o coronavírus é a conscientização.

8. Porque a cidadania é a melhor arma contra o Coronavírus.

9. Uma Película de Biocobre é a nova arma no combate ao Coronavírus.

10. Soro obtido de cavalos pode ser arma contra a covid-19.

11. Spray nasal com anticorpos de galinhas pode ser a próxima arma contra a covid-19.

12. Vacina BCG contra a tuberculose pode transformar-se na nova arma contra a Covid-19.

13. A atividade física regular pode ser uma arma contra a Covid-19.

14. O isolamento social é a nossa principal arma contra a Covid-19.

15. Vacina contra o sarampo modificada pode ser arma contra a Covid-19.

16. A melhor arma contra a covid-19 é o uso de máscaras faciais.

17. Nanotecnologia pode ser arma contra a Covid-19.

18. Informação jornalística como arma contra o Coronavírus e qualquer foco de desinformação.

19. Esperança, para antes da vacina chegar, é a dexametasona como arma no combate à Covid-19.

20. Anticorpo super potente que pode funcionar como uma arma contra a covid-19.

As 20 instanciações do elemento-fonte "arma" selecionadas podem ser divididas em dois grupos. O primeiro grupo (A) diz respeito a "armas" no sentido mais material, ou seja, produtos desenvolvidos, principalmente, por cientistas em busca de tais armas. No início da pandemia, em março de 2020, a “corrida por armas" já era anunciada no website Canal Tech:

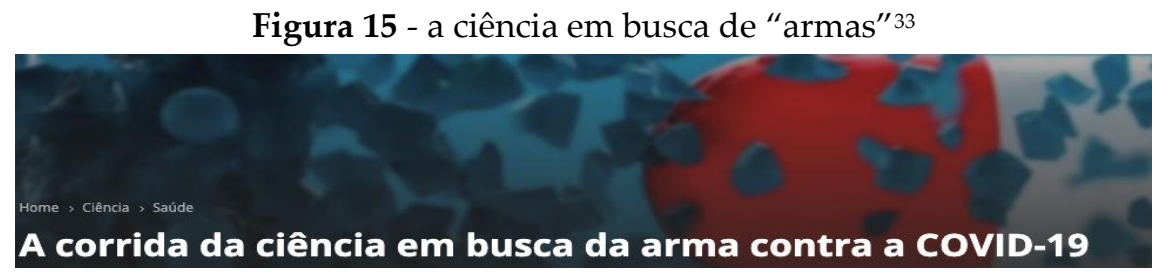

33 Fonte: https://canaltech.com.br/saude/a-corrida-da-ciencia-em-busca-da-arma-contra-acovid-19-162160/. Acesso em: 20 dez. 2020. 
As instanciações do elemento "armas", no grupo A, são as apresentadas em (5):

(5) Lâmpadas ultravioletas; película de Biocobre; soro obtido de cavalos, Spray nasal com anticorpos de galinhas; vacina BCG; vacina de sarampo modificada; nanotecnologia; anticorpo super potente; dexametasona, anticorpos monoclonais.

Já no grupo (B), em (6), as "armas" consistem em ações ou comportamentos humanos, ou algum tipo de conhecimento a ser adquirido (informação) com o propósito de "conscientização", que podem, direta ou indiretamente, proteger o indivíduo, de alguma forma, contra a contaminação pelo SARS-CoV-2.

(6) Lavar as mãos; isolamento social; higiene; prevenção; sanitização; conscientização; cidadania; atividade física regular; uso de máscara faciais; informação jornalística.

Ou seja, as armas podem ser externas ou internas: as primeiras, do grupo A, envolvem o "bom combate' de "guerreiros-cientistas" e suas criações; as segundas, do grupo B, dizem respeito a mudanças de comportamento de cada indivíduo, desde hábitos de higiene e usos de máscaras, a mudanças de atitude, no sentido de obter mais e melhores informações, que levariam à conscientização de seu papel na prevenção de si próprio e de outros, passando de simples agonista para antagonista no combate à COVID-19.

As armas do grupo B parecem ter um grau de metaforicidade mais alto do que as do grupo A, uma vez que suas instanciações consistem, em sua maioria, em comportamentos, tanto em forma de ação, quanto de atitude, que se distanciam, cognitivamente, de armas materiais. Dessa forma, seriam, mais nitidamente, "armas metafóricas". Medicamentos, soros, vacinas modificadas etc., por sua vez, pela sua materialidade enquanto "produtos" a serem usados no "combate", teriam um grau de metaforicidade mais baixo, aproximando-se, cognitivamente, do frame prototípico (LAKOFF, 1987) de ARMA.

É interessante constatar que, nessas 10 páginas examinadas, não apareceu a expressão "vacina contra COVID-19/Coronavírus" entre as instanciações de 
"armas". Uma hipótese que surge é a de que a vacina seria a arma final, derradeira e, como já dito anteriormente, uma "arma-nuclear", que poria fim à guerra contra o SARS-CoV-2. Isso parece se evidenciar em uma das entradas (n.19) da figura 14, em que o enunciador, antes de anunciar a "arma" em questão (no caso, o medicamento "dexametasona"), afirma que essa seria direcionada para "antes da vacina chegar". É como se a vacina (algumas das cento e vinte em atual desenvolvimento) estivesse, conceptualmente, em um estágio, ou mesmo em um novo patamar, além de todas as outras possíveis "armas"; daí a enorme esperança nela depositada. O nicho metafórico, a seguir, explora, humoristicamente, por meio de muitos mapeamentos online, a metáfora situada (VEREZA, 2016) vacina é bebida alcóolica, que perspectiva a vacina (as cinco em estágio de desenvolvimento e implementação mais adiantado em dezembro de 2020) como algo libertador e, portanto, extremamente desejável:

GARÇOM ${ }^{34 !}$

O amigo Léo Jaime falou que seu corpo só pensa em uma Pfizer estupidamente gelada, a -75 graus, com direito a repeteco. É o nosso trago sonhado. A birita que não pode faltar à mesa. [...] Meu paladar não é tão exigente. Pode vir o coquetel da Moderna (EUA); saquê da Coronovac (China); a vodka da Sputinik (Rússia); o gin da AstraZenec (Reino Unido); o Masala chai da Bharat Biotech (Índia). Aceito qualquer uma das opções do cardápio, para sentir os efeitos colaterais dos abraços, do cafuné e do colo. Para voltar a viajar, a me banhar nas praias, a pular em shows, a gritar nos estádios de futebol. Quero mais me embriagar de viver, tomar um porre de alívio e de felicidade, experimentar a ressaca da ternura. Que a vacina contra a COVID-19 não demore a chegar. A abstinência emocional já foi longa.

\section{CONSIDERAÇÕES FINAIS}

A reflexão desenvolvida ao longo deste artigo explorou a hipótese de que a metáfora conceptual COMBATE À COVID-19 É GUERRA, com seus muitos e consistentes mapeamentos, estrutura parte significativa da conceptualização da pandemia do vírus SARS-CoV-2, que abalou o mundo, tanto no nível da saúde

\footnotetext{
${ }^{34}$ Fonte anônima. Texto recebido pelo aplicativo de conversas WhatsApp, em 02 de janeiro de 2020.
} 
(física e mental), quanto no da economia, política e relações sociais, durante grande parte do ano de 2020 e provavelmente de 2021. O inimigo tem se mostrado tão ameaçador e devastador que evocar o domínio da GUERRA, com seus muitos elementos estruturantes, para se conceptualizar (pensar, falar e agir) o seu combate, parece uma operação cognitiva até certo ponto previsível.

Esta hipótese foi explorada por uma investigação desenvolvida com base em dados provenientes do Corpus do Português e da Plataforma GOOGLE, a partir de uma abordagem tanto dedutiva quanto indutiva (dados para verificar uma hipótese e, ao mesmo tempo, para levantar-se e explorar outras). O foco foi direcionado às instanciações de elementos-fonte, considerados, nesta pesquisa, fundantes da metáfora conceptual: o inimigo, o agonista/soldado/herói, a linha de frente do combate, e as armas. Em seu conjunto, os mapeamentos realizados a partir desses elementos-fonte perspectivam os elementos-alvo (a pandemia, a doença e o vírus, como inimigos; profissionais da saúde, como soldados e heróis; medicações e comportamentos sanitários como armas, entre outros) enquadrando-os como peças-chave do cenário de GUERRA.

Na guerra contra a COVID-19, outros fenômenos humanos também são assim perspectivados. Nos dados encontramos as seguintes expressões: "guerra contra o negacionismo", "guerra contra o descaso governamental", "guerra contra o obscurantismo" e, paradoxalmente, "guerra contra a saúde" e "guerra conta vacina". Essa última, em uma busca na Plataforma GOOGLE, resultou em 46.600 entradas - o que mostra como a expressão está presente em discursos circulantes sobre a pandemia. Ou seja, a sociedade parece sentir que o inimigo não é apenas o vírus. Esse esteve e está acompanhado por outros, de natureza mais abstrata, que impedem um combate mais eficiente e uma expectativa mais promissora de vitória.

As perspectivações decorrentes e licenciadas pela metáfora da GUERRA têm sido problematizadas por alguns estudiosos, principalmente no contexto de 
doenças. No caso do câncer, por exemplo, Marron et al. (2020) afirmam que, em relação ao que chamam "linguagem bélica",

Algumas pesquisas demonstram que este linguajar está presente em $2 / 3$ de nossas conversas com os pacientes, uma "luta" contra um "inimigo poderoso", travamos uma "batalha" contra as probabilidades, estamos "unidos nesta luta" contra um "inimigo comum" [....] Apesar de seu apelo, no entanto, não está claro se as metáforas de guerra são benéficas. As guerras têm vencedores e perdedores e, na guerra, o vencedor geralmente é aquele que tiver mais força, mais recursos e combatentes mais dispostos. É esta a mensagem que esperamos enviar às pessoas com câncer? Se o câncer é uma guerra, podemos não vencer, não importa como definamos vitória. Quando alguém morre de câncer, é porque não lutou com força suficiente? Metáforas de violência expressas por pacientes com câncer, embora sejam valiosas para alguns, muitas vezes levam a sentimentos de impotência, culpa e fatalismo. (MARRON et al., 2020, p. 625).

Os autores levantam as mesmas restrições às metáforas de guerra no cenário da COVID-19, ressaltando o que consideram uma falácia da "metáfora do herói" como atributo dos profissionais de saúde. Segundo eles, esses profissionais não devem ser conceptualizados como soldados, uma vez que não são voluntários, não têm a expectativa de grande risco de morte (o que tem acontecido com frequência) e não são os únicos profissionais diretamente envolvidos no combate, como já foi mencionado anteriormente neste artigo.

As possíveis inadequações da conceptualização metafórica do COMBATE À COVID-19 são levantadas por outros autores e até mesmo jornalistas ${ }^{35}$. Concluo este artigo posicionando-me neste debate, com base em dois pontos principais: um de caráter empírico, outro teórico.

O primeiro se apoia na pesquisa de Semino et al. (2018), pesquisadoras que investigaram as metáforas nas falas de pacientes terminais de câncer. Duas metáforas conceptuais predominantes foram identificadas: CÂNCER É GUERRA; CÂNCER É VIAGEM. Em relação à primeira, que nos interessa mais

${ }_{35}$ Por exemplo: https://jornal.ufg.br/n/131433-metafora-de-guerra-sobre-a-pandemia-*afastaestimulo-a-cooperacao; https://drauziovarella.uol.com.br/coronavirus/pandemia-nao-eguerra/; https:/www.jornalopcao.com.br/reportagens/a-metafora-da-guerra-em-tempos-depandemia-248941/. Ambos os acessos em: 28 dez. 2020. 
diretamente, as autoras identificaram aspectos positivos e negativos, dependendo de como cada instanciação da metáfora é perspectivada no discurso: se por um lado, a batalha contra o câncer pode motivar o surgimento do espectro da derrota e da força e capacidade individual do soldado (que pode não existir devido aos efeitos da doença), por outro lado, o combate perspectiva a motivação para o enfrentamento, a coragem para lutar e a confiança da possibilidade da vitória. Ou seja, os efeitos de sentido podem variar não apenas de acordo com o mapeamento off-line evocado, mas com a perspectivação discursiva no contexto enunciativo online (VEREZA, 2013). Em outras palavras, os vários mapeamentos online não são intrinsicamente positivos ou negativos. A perspectivação não é só cognitiva: ela é sempre cognitivo-discursiva.

O segundo ponto diz respeito ao que Reddy (1993) chama "conflito de frames" (frame conflict). Ao descrever a "metáfora do conduto" (conduit metaphor), empiricamente evidenciada por muitas expressões linguísticas encontradas na língua inglesa, Reddy (1993) problematiza a sua coerência e adequação, e propõe uma outra: a metáfora dos construtores. Apesar dessa metáfora parecer ser bem fiel ao que de fato acontece na comunicação, o próprio Reddy não acredita que possamos simplesmente deixar de usar a primeira e passar a usar a segunda, para falarmos e pensarmos de uma maneira mais adequada ao que realmente acontece.

Da mesma forma, creio que a metáfora da guerra, já há muito tempo enraizada em nossa língua e cultura, por se apoiar, corporeamente, no esquema imagético de FORÇA (JOHNSON, 1987) e, socialmente, em uma história pontuada por guerras e antagonismos entre os homens, não pode ser deliberadamente excluída de nosso sistema conceptual e substituída por outra mais "pacífica". Além disso, como mostra a pesquisa de Semino et al. (2018), não parece ser fato que a metáfora da GUERRA incite necessariamente um espírito beligerante nas pessoas. Tudo vai depender da maneira que ela for perspectivada em um contexto sociodiscursivo específico. 
Isso não quer dizer que não devamos estar cada vez mais conscientes das metáforas nossas de cada dia; de como a guerra, perspectivada no seu sentido de luta, um movimento em direção ao objetivo e a nossos ideais, pode ser perspectivada em direção à construção de um mundo melhor. Os domínios, com seus elementos-fonte habitam nosso sistema conceptual socialmente compartilhado; o que iremos perspectivar por meio de mapeamentos seletivos é o que pode vir a fazer a diferença. E estarmos todos juntos, em batalha, contra a COVID-19, com todas as armas possíveis, e contra os obstáculos que impedem ou dificultam a eliminação desse vírus letal, parece ser uma perspectivação significativamente positiva. Espero que a história venha a mostrar que a humanidade saiu vitoriosa - e mais unida - desta guerra. E que a nossa "falta de palavras", gerada pelo regozijo da vitória, passe a mobilizar metáforas mais solidárias.

\section{REFERÊNCIAS}

BRONZATO, L. O segredo do sucesso que a gramática e a metáfora não escondem. In: VEREZA, S. Sob a ótica da metáfora. Niterói: EDUFF, 2012. p.193-211.

CAMERON, L.; STELMA J. Metaphor clusters in discourse. Journal of Applied Linguistics, Sheffield, v. 1, n. 2, p. 107-136, 2004.

CARVALHO, S. N. A guerra nas palavras: uma análise crítica da metáfora conceptual na retórica do Presidente George W. Bush e de seus colaboradores, 2006. 148 f. Tese (Doutorado em Estudos Linguísticos). Universidade Federal Fluminense, Niterói.

CARVALHO, S. N. As forças armadas contra a dengue no Rio de Janeiro: uma guerra linguistico-discursiva através da metáfora conceptual. Revista Philologus, Niterói, v. 15, n. 43, p. 79-92, 2009.

DIENSTBACH, D. Metaforicidade: um aspecto do gênero. Fórum Linguístico, v. 14, n. 1, p. 1767-1778, 2017.

GEERAERTS, D. et al. (Orgs.). Cognitive Linguistics: basic readings. Berlin: Mouton de Gruyter, 2006.

GIBBS, R. W. Metaphor wars: conceptual metaphors in human life. Cambridge, Cambridge University Press, 2017.

FARACO, S. Conceptualizações metafóricas de tempo no discurso de brasileiras. In: VEREZA, S. Sob a ótica da metáfora. Niterói: EDUFF, 2012. p. 65-118. 
FAUCONNIER, G. Mappings in thought and language. Cambridge: Cambridge University Press. 1997.

FILIPCZUK, S. Analysing Metaphorical Political Discourse in the L2 Academic Classroom. Procedia - Social and Behavioral Sciences, v. 228, n. 2, p.329-334, 2016.

FILLMORE, C. Frame semantics. In: GEERAERTS, D. et al. (Orgs.). Cognitive Linguistics: basic readings. Berlin: Mouton de Gruyter, 2006. p. 373-400.

FILLMORE, C. Semântica de frames. In.: Cadernos de Tradução, Porto Alegre, n. 25, juldez, 2009.

GEERAERTS, D. et al. (Eds.). Cognitive Linguistics: basic readings. Berlin: Mouton de Gruyter, 2006. p. 24-39.

JOHNSON, M. The body in the mind: the bodily basis of meaning, imagination and reason. Chicago: University of Chicago Press, 1987.

KARLBERG, M.; BUELL, L. (2005). Deconstructing the "War of all against all": the prevalence and implications of war metaphors and other adversarial news schema in TIME, Newsweek, and Maclean's. Journal of Peace and Conflict Studies, Fort Lauderdale, v. 12, n.1, p. 22-39, 2005.

KIMBERLY, T.; HANINGER, K. Violence in E-Rated video games, Chicago, JAMA, v. 286, n. 5, p. 591-598, 2001.

KÖVECSES, Z. Where metaphors come from: reconsidering context in metaphor. Oxford: Oxford University Press, 2016.

LAKOFF, G. The contemporary theory of metaphor In: ORTONY, A. (Org.). Metaphor and thought. 2. ed. Cambridge, MA: Cambridge University Press, 1993.

LAKOFF, G. Women, Fire, and Dangerous Things: what categories reveal about the mind. Chicago: Chicago University Press, 1987.

LAKOFF, G.; JOHNSON, M. Metáforas da vida cotidiana. Tradução por Grupo GEIM. Campinas/São Paulo: EDUC/Mercado de Letras, 2002 [1980].

LANGACKER, R. Essentials of cognitive grammar. Nova Iorque: Oxford University Press, 2013.

LING, S. A Cognitive study of war metaphors in five main areas of everyday English: politics, business, sport, disease and love. Kristianstad University School of Teacher Education. Disponível em: http://www.divaportal.org/smash/get/. Acesso em: 18 dez. 2020.

MARRON, J. et al. Waging war on war metaphors in cancer and COVID-19. JCO Oncology Practice, Alexandria, v. 16 n. 10.p. 624-628, 2020. 
PENIDO, A. A retórica militar camuflada na "guerra" ao coronavírus. Tricontinental, 12 maio 2020. Disponível em: https://www.thetricontinental.org/pt-pt/brasil/a-retoricamilitar-camuflada-na-guerra-ao-coronavirus/. Acesso em: 20 dez. 2020.

REDDY, M. The conduit metaphor. In: ORTONY, A. Metaphor and Thought. 2ed. Cambridge: Cambridge University Press, 1993, p. 78-112.

SALOMÃO, M. M. M. A questão da construção do sentido e a revisão da agenda dos estudos da linguagem. Veredas- Revista de Estudos Linguísticos, Juiz de Fora, v.3, n.1, p. 61-79, 1999.

SEGUNDO, P. A relevância da noção de perspectivação conceptual (construal) no âmbito dos estudos do texto e do discurso: teoria e análise. Letras, Santa Maria, v. 27, n. 54, p. 69-100, 2017.

SEMINO, E. et al. Metaphor, cancer and the end of life: a corpus-based study. Amsterdam: John Benjamins, 2018.

SILVA, A. S. Perspectivação conceptual e gramática. Revista Portuguesa de Humanidades Estudos Linguísticos, Braga, v. 12, n.1, p. 17 - 44, 2008.

SONTAG, S. Aids and its metaphors. New York: Farrar, Straus \& Giroux, 1989.

SONTAG, S. Illness as metaphor. New York: Farrar, Straus \& Giroux, 1978.

STOCK, V. Pandemia do Corona vírus traz à tona novas palavras e termos. Diário da Região, 14 maio 2010.2 Disponível https://www.diariodaregiao.com.br/cidades/2020/05/1193621-pandemia-docoronavírus-traz-a-tona-novas-palavras-e-termos.html. Acesso em: 07 out. 2020.

TALMY, L. Force Dynamics in language and cognition. Cognitive Science, Hoboken, v. 12, n.1, p. 49-100, 1988.

TURNER, M. The literary mind. Oxford: Oxford University Press, 1998.

VEREZA, S. A palavra como arma: metáforas de guerra na conceptualização do antagonismo verbal. Diadorim, Rio de Janeiro, v. 22, n. 2, p.367-385, 2020.

VEREZA, S. "Metáfora é que nem...": cognição e discurso na metáfora situada. Revista Signo, Santa Cruz do Sul, 38, n. 65, 2013.

VEREZA, S. O lócus da metáfora: linguagem, pensamento e discurso. Cadernos de Letras da UFF, Niterói, v. 41, n. 1, p. 199-212, 2010.

WICKE, P.; BOLOGNESI, M. Framing COVID-19: How we conceptualize and discuss the pandemic on Twitter. PLoS ONE, São Francisco, v. 15 n. 9. p.1-24, 2020.

Nota do editor:

Artigo submetido para avaliação em: 30 de novembro de 2020.

Aprovado em sistema duplo cego em: 29 de janeiro de 2021. 